\title{
Puhdas sinimailaskasvusto tulee niittää ajoissa
}

\author{
Kirsi Mäkiniemii ${ }^{1)}$, Jussi Javanainen ${ }^{2)}$, Heidi Lappalainen ${ }^{2)}$, Markku Niskanen ${ }^{1)}$ ja Mervi Seppänen ${ }^{3)}$ \\ ${ }^{1)}$ Luonnonvarakeskus (Luke), Luonnonvarat ja biotuotanto/Tuotantojärjestelmät, Alapääntie 104, \\ 61400 YLISTARO, etunimi.sukunimi@luke.fi \\ ${ }^{2)}$ Seinäjoen ammattikorkeakoulu (SeAMK), Elintarvike ja maatalous, Ilmajoentie 525, 60800 \\ ILMAJOKI, etunimi.sukunimi@seamk.fi \\ ${ }^{3)}$ Helsingin yliopisto, Maataloustieteiden laitos, Latokartanonkaari 5, 00014 HELSINGIN \\ YLIOPISTO,mervi.seppanen@helsinki.fi
}

\section{Tiivistelmä}

Kiinnostus sinimailasen viljelyyn on lisääntynyt Suomessa, vaikka mailaset ovat suhteellisen vaativia kasveja. Useimmissa tapauksissa sinimailanen on mukana heinäpitoisissa tai -valtaisissa seoksissa ja puhtaat sinimailaskasvustot ovat harvinaisempia. Puhtaiden sinimailaskasvustojen niittorytmille ei ole varsinaisia kotimaisia viljelijäohjeita, ja usein niihin sovelletaan ulkomaisia ohjeita. Suomessa virallisten lajikekokeiden ohjeet on mukailtu ulkomaisista ohjeista: ensimmäinen niitto tehdään kukinnan alkaessa ja toinen niitto elokuun puolivälissä tai viimeistään elo-syyskuun vaihteessa, eikä kolmatta niittoa suoriteta ollenkaan. Viljelijäohjeissa sinimailasseosten korjuukerroiksi ohjeistetaan kuitenkin jopa 3 - 4 niittokertaa Pohjois-Suomessakin.

Luonnonvarakeskus Ylistarossa on selvitetään vuosina 2015 - 2016 viiden sinimailaslajikkeiden (Alexis, Artemis, Lavo, Live ja Nexus) kehitysrytmiä, sadontuottoa ja rehulaatua kolmen niiton strategiassa. Tässä artikkelissa selvitetään ensimmäisen vuoden tulokset.

Lehtialaindeksin (LAI) kehittymisessä ei ollut lajikkeiden välisiä merkittäviä eroja muutamaa toisen sadon ajankohtaa lukuun ottamatta, mutta satojen LAI-maksimit saavutettiin jo ennen kukinnan alkua, toisessa sadossa jopa kaksi viikkoa ennen kukinnan alkua. LAI-arvot olivat hieman korkeammat toisessa sadossa kuin ensimmäisessä sadossa, mutta niiden saavuttamiseen vaadittiin korkeampi tehoisa lämpösumma $\left(180^{\circ} \mathrm{Cvrk}\right.$ ensimmäisessä sadossa, $350^{\circ} \mathrm{C} v r k$ toisessa sadossa).

Lajikkeiden välillä ei havaittu tilastollisesti merkitseviä eroja kahden ensimmäisen niiton satomäärissä, kolmannessa niitossa satotasoerot olivat selviä. Ensimmäisen niiton satotaso oli keskimäärin $3400 \mathrm{~kg} \mathrm{ka} / \mathrm{ha}$, toisen $3910 \mathrm{~kg} \mathrm{ka} / \mathrm{ha}$ ja kolmannen $1940 \mathrm{~kg} \mathrm{ka} / \mathrm{ha}$ eli vuoden keskimääräinen satotaso oli $9250 \mathrm{~kg} \mathrm{ka} / \mathrm{ha}$. Ensimmäisessä niitossa D-arvot (keskimäärin $666 \mathrm{~g} / \mathrm{kg} \mathrm{ka}$ ) olivat hieman nurmiheinille asetetun tavoitetason (noin $680-700 \mathrm{~g} / \mathrm{kg} \mathrm{ka}$ ) alapuolella. Raakavalkuaispitoisuudet olivat keskimäärin lähes $200 \mathrm{~g} / \mathrm{kg}$ ka ja iNDF-pitoisuudet lähes $120 \mathrm{~g} / \mathrm{kg} \mathrm{ka}$. Lajikkeiden rehuarvot eivät eronneet toisistaan. Toisessa sadossa D-arvot olivat erittäin matalia (keskimäärin $592 \mathrm{~g} / \mathrm{kg} \mathrm{ka}$ ) kaikilla lajikkeilla, vaikka niitto tehtiin aivan kukinnan alkuvaiheessa suosituksen mukaisesti. Sekä iNDF-pitoisuudet että raakavalkuaispitoisuudet olivat toisessa sadossa erityisen korkeita (raakavalkuainen noin $190 \mathrm{~g} / \mathrm{kg}$ ka ja iNDF $180 \mathrm{~g} / \mathrm{kg} \mathrm{ka}$ ). Kolmannen sadon D-arvo oli matalahko (keskimäärin $633 \mathrm{~g} / \mathrm{kg} \mathrm{ka})$ ja iNDF-pitoisuus korkeahko (145 g/kg ka), valkuaispitoisuudet korkeita (lähes $260 \mathrm{~g} / \mathrm{kg} \mathrm{ka}$ ). Sinimailasten sokeripitoisuudet olivat heinäkasveihin verrattuna matalia, erityisesti kolmannessa niitossa. Sadon iNDF-pitoisuuden ja D-arvon välillä havaittiin lähes täydellinen negatiivinen korrelaatio.

Puhtaan sinimailaskasvuston ensimmäinen niitto olisi tämän kokeen tulosten perusteella järkevää tehdä viimeistään nuppuvaiheen lopulla. Rehuarvotulokset erityisesti toisesta niitosta viittaavat siihen, että puhdas sinimailaskasvusto menettää sulavuutensa nopeasti jälkikasvussa ja korjuu olisi tehtävä huomattavasti aikaisemmalla kehitysasteella, vaikkakin tuloksiin liittyy epävarmuutta nimenomaan sinimailaselle tehtyjen NIR-kalibraatioiden puuttumisen takia. Niiton aikaistamista tukevat havainnot siitä, että LAI-maksimit saavutettiin toisessa sadossa jo pari viikkoa ennen niittoa suosituskehitysasteella. Tämän kokeen tulosten perusteella Suomen oloissa optimi voisi olla 5-6 viikkoa ensimmäisen niiton jälkeen. D-arvon ja kuitupitoisuuden kehityksen ennustajina saattavat toimia kasvuston korkeus ja kehitysaste.

\section{Asiasanat}

Sinimailanen, kasvuston kehitys, LAI, niittoaika, rehuarvot, D-arvo 


\section{Johdanto}

Kiinnostus sinimailasen viljelyyn on lisääntynyt Suomessa, vaikka mailaset ovat suhteellisen vaativia kasveja kasvuolojen ja maalajin suhteen. Useimmissa tapauksissa sinimailanen on mukana heinäpitoisissa tai -valtaisissa seoksissa ja puhtaat sinimailaskasvustot ovat harvinaisempia. Kasvuston optimaalista korjuuaikaa arvioidaan sen kehitysasteen perusteella: ulkomaisessa ohjeistuksessa sinimailanen suositellaan korjattavaksi myöhäisellä nuppuasteella (esim. Myers \& van Keuren) tai kun tietty lämpösumma on kertynyt ja mahdollisesti jopa myöhemmin kuin heinä-sinimailasseokset (Kaatz, 2015). Kotimaisessa ohjeistuksessa suositellaan viljelyä seoksina ja korjuuta nuppuvaiheen lopulla tai kukinnan alkaessa (Vuorinen \& Takala, 1993; ProAgria Oulu).

Puhtaiden sinimailaskasvustojen niittorytmille ei ole varsinaisia kotimaisia viljelijäohjeita tai ne ovat vanhoille lajikkeille annettuja (vrt. Vuorinen \& Takala, 1993). Suomessa virallisten lajikekokeiden ohjeet on mukailtu ulkomaisista käytännöistä ja lajikekoeohjeen mukaan ensimmäinen niitto tehdään kukinnan alkaessa ja toinen niitto elokuun puolivälissä - viitteellistä kehitysastetta ei ole annettu - tai viimeistään elo-syyskuun vaihteessa, eikä kolmatta niittoa suoriteta ollenkaan (Niskanen, 2013). Viljelijäohjeissa sinimailasseosten korjuukerroiksi ohjeistetaan kuitenkin jopa 3 - 4 niittokertaa Pohjois-Suomessakin (ProAgria Oulu).

Kolmen niiton strategian sopivuutta sinimailaselle on ollut tarve selvittää. Luonnonvarakeskus Ylistarossa toteutettavan sinimailaskokeen tarkoituksena on selvittää sinimailaslajikkeiden kehitysrytmiä, talvenkestävyyttä, sadontuottoa ja rehulaatua kolmen niiton strategiassa. Tässä artikkelissa selvitetään ensimmäisen vuoden tulokset.

\section{Aineisto ja menetelmät}

Luonnonvarakeskus Ylistarossa tutkitaan vuosina 2014 - 2016 sinimailaslajikkeiden talvenkestävyyttä, sadon ja laadun kehitystä sekä näiden yhteyksiä toisiinsa. Koe on perustettu kesällä 2014 neljänä kerranteena ja puhtaina sinimailaskasvustoina viidellä eri lajikkeella: Alexis, Artemis, Nexus, Live ja Lavo. Kylvötiheys oli kaikilla lajikkeilla $700 \mathrm{kpl} / \mathrm{m}^{2}$. Maalajina on multava $\mathrm{HHt}$, jonka $\mathrm{pH}$ on 6,3. Perustamislannoituksessa annettiin väkilannoitteena $30 \mathrm{~kg} \mathrm{~N} / \mathrm{ha}, 3 \mathrm{~kg} \mathrm{P} / \mathrm{ha}$ ja $3 \mathrm{~kg} \mathrm{~K} / \mathrm{ha}$. Ensimmäisenä satovuonna kevätlannoitus tehtiin heti kasvukauden alettua antamalla väkilannoitteena $40 \mathrm{~kg} \mathrm{~N} / \mathrm{ha}, 4 \mathrm{~kg} \mathrm{P} / \mathrm{ha} \mathrm{ja} 4 \mathrm{~kg} \mathrm{~K} / \mathrm{ha}$. Toisen ja kolmannen sadon lannoitukset tehtiin muutama päivä edeltäneen niiton jälkeen antamalla väkilannoitteena toiselle sadolle $33 \mathrm{~kg} \mathrm{~N} / \mathrm{ha}, 10 \mathrm{~kg} \mathrm{P} / \mathrm{ha} \mathrm{ja} 41 \mathrm{~kg}$ $\mathrm{K} / \mathrm{ha}$ ja kolmannelle sadolle $20 \mathrm{~kg} \mathrm{~N} / \mathrm{ha}, 0 \mathrm{~kg}$ P/ha ja $38 \mathrm{~kg} \mathrm{~K} / \mathrm{ha}$. Kasvustojen lehtialaindeksin (LAI) kehitystä ja siten viitteellistä satomäärän kehitystä seurattiin kaikilla satokerroilla viikoittaisilla mittauksilla (LAI-2000 Plant Canopy Analyzer, LI-COR Inc., Lincoln, Nebraska, USA). Tarkasteluvaiheessa LAI-tulokset peilattiin kasvuston kehitykseen vaikuttaneeseen tehoisaan lämpösummaan.

Ensimmäisen sadon niitto ajoitettiin myöhäiselle nuppuvaiheelle (16.6.2015), toisen sadon korjuu aivan kukinnan alkuun (5.8.2015, jolloin $5 \%$ nupuista avautunut) ja kolmannen sadon niitto tehtiin syyskuun alkupuolella (9.9.92015), kun pituuskasvu ja LAI-arvojen kehitys näytti pysähtyvän. Niittokorkeus oli ensimmäisessä ja toisessa niitossa $8 \mathrm{~cm}$, kolmannessa niitossa niittokorkeus oli 10 $\mathrm{cm}$, jotta kasvustoa jäisi jäljelle hieman enemmän talvehtimismenestystä ajatellen. Ennen niittoa kasvustoista mitattiin LAI ja kasvuston keskimääräinen ojennettu korkeus maanpinnasta $(\mathrm{cm})$ sekä arvioitiin visuaalisesti lakoisuus (\% kasvustosta) ja kehitysaste $\mathrm{BBCH}$-asteikolla (Lancashire ym. 1991). Satotiedot ja mittaukset ovat aina koeruuduttaisia $(n=4)$. Niittonäytteet kuivattiin $24 \mathrm{~h}+60$ ${ }^{\circ} \mathrm{C}$ :ssa ja niistä määritettiin kuiva-ainepitoisuus sekä keskeisimmät rehuarvot (NIRS sinimailaselle tilattuna/Valio Oy:n käyttämä palkokasvikalibraatio, Valio Oy:n rehulaboratorio, Seinäjoki). Ensimmäisen sadon niitossa lajikkeista on ainoastaan koejäsenittäin yhdistetyt rehuarvotiedot käytettävissä $(n=1)$, sen sijaan toisen sadon niitosta tulokset ovat koeruuduittain ja analyysit tehtiin kolmen kerranteen näytteistä $(\mathrm{n}=3)$.

Tulokset laskettiin SAS-tilastolaskentaohjelmalla (versio 9.4 ja SAS Enterprise Guide 7.1, SAS Institute Inc., Cary, NC, USA). Varianssianalyyseissä käytettiin sekamallia (MIXED Procedure), jossa lajike oli kiinteä muuttuja, kerranne satunnaismuuttuja ja tilastollisen merkitsevyyden raja $p$-arvo 0,05 . Parivertailuissa käytettiin Tukeyn testiä ja merkitsevyyden rajana pidettiin $p$-arvoa 0,05 , tendenssin rajana $p$-arvoa 0,10 . Korrelaatioita selvitettiin regressioanalyysillä (REG Procedure). 


\section{Tulokset ja tulosten tarkastelu}

\section{Kasvustojen lehtialaindeksin kehitys}

Lehtialaindeksin (LAI) kehittymisessä ei ollut lajikkeiden välisiä merkittäviä eroja ensimmäisessä tai kolmannessa sadossa, mutta toisessa sadossa erot lajikkeiden välillä havaittiin puolessa mittauskerroista (Kuva 1). Käytännön kannalta keskeisimmät erot toisessa sadossa havaittiin 350 - 420 ${ }^{\circ}$ Cvrk:n kohdalla vaiheessa, jolloin lajikkeiden LAI-kehitysrytmi alkoi erota toisistaan: Artemiksen ja Lavon LAI-arvot jatkoivat kasvua, kun taas muiden lajikkeiden LAI-arvot olivat jo laskusuunnassa. Toisen sadon LAI-maksimit olivat hieman korkeammat kuin ensimmäisessä sadossa, mutta niiden saavuttamiseen vaadittu tehoisa lämpösumma $\left({ }^{\circ} \mathrm{Cvrk}\right)$ poikkesi toisistaan: ensimmäisessä korjuussa LAI-maksimi saavutettiin jo $180{ }^{\circ} \mathrm{C} v r k: n$ kohdalla, mutta toisessa sadossa vasta $350{ }^{\circ} \mathrm{Cvrk}: \mathrm{n}$ paikkeilla. Osaksi tämä johtui siitä, että toisen sadon lehtialan palautumiseen ensimmäisen niiton jälkeen kului $150^{\circ} \mathrm{Cvrk}$ ja LAI-kehitysvauhti oli hitaampi kuin ensimmäisen sadon kehityksen aikana. Kolmannen sadon LAI-maksimi oli selvästi matalin eikä sitä välttämättä saavutettu täysin ennen syksyn viimeistä niittoa, sillä viimeisten kahden havaintoajankohdan LAI-arvo vaikutti olevan vielä kasvusuuntainen.
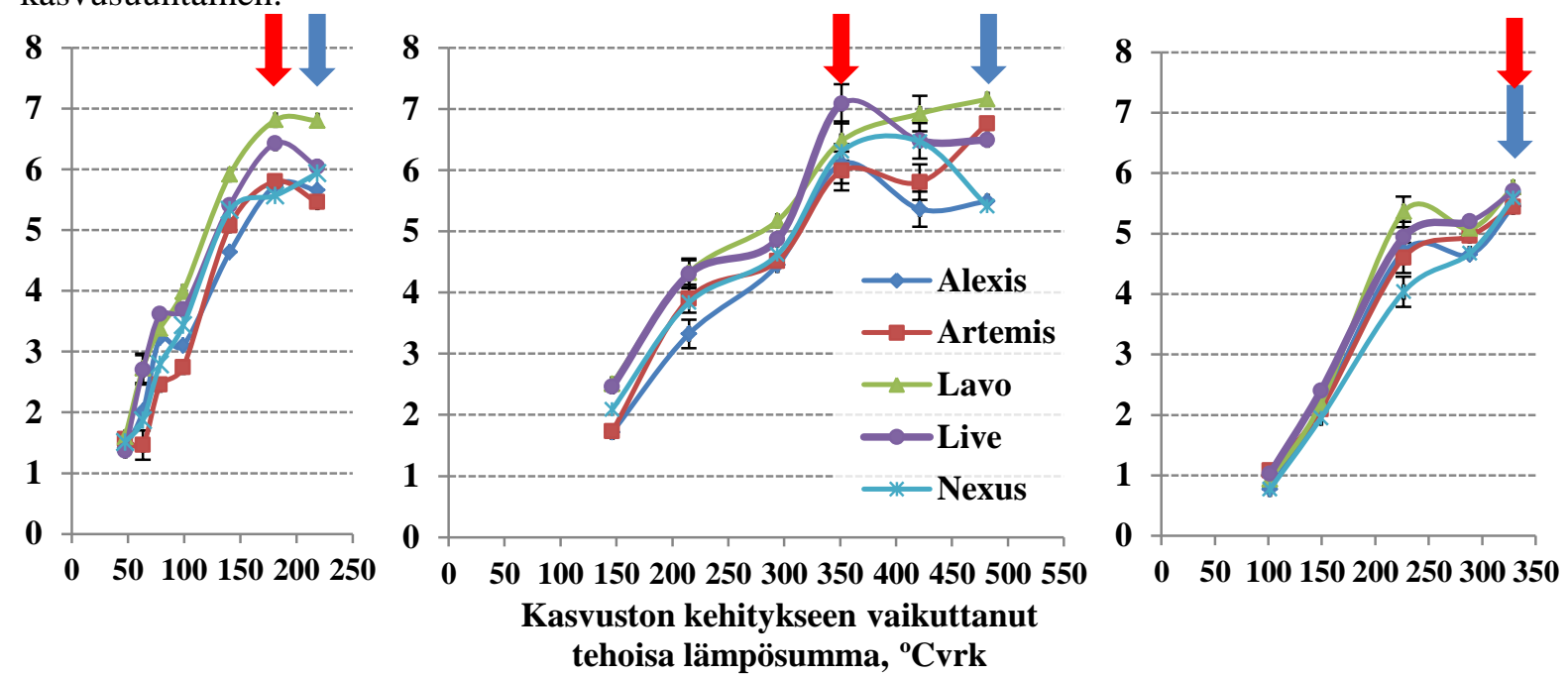

Kuva 1. Puhtaiden sinimailaskasvustojen lehtialaindeksin (LAI) kehitys ensimmäisen (A), toisen (B) ja kolmannen (C) sadon kehittyessä kasvuun vaikuttaneen tehoisan lämpösumman $\left({ }^{\circ} \mathrm{Cvrk}\right)$ suhteessa. Ensimmäisen sadon nollapiste on kasvukauden alku ja toisen ja kolmannen sadon nollakohta edellisen sadon niittopäivä. Niittojen ajankohdat on merkitty sinisellä nuolella ja LAI-maksimien saavuttamishetket punaisella nuolella. Hajontana on esitetty kunkin mittausajankohdan keskiarvojen keskivirhe (SEM) silloin, kun lajikkeiden välinen ero on tilastollisesti merkitsevä $(p<0,05)$.

\section{Satomäärät ja kasvuston korkeus, lakoisuus ja kehitysaste}

Lajikkeiden välillä ei havaittu tilastollisesti merkitseviä eroja ensimmäisen ja toisen niiton kuivaainesadossa lukuun ottamatta Live-lajikkeen korkeampaa satotasoa toisessa niitossa $(p<0,10)$. Sen sijaan kolmannen sadon niitossa erot lajikkeiden välillä olivat merkitsevät: Lavon ja Nexuksen satotaso oli muita alhaisempi (Taulukko 1). Ensimmäisen niiton kuiva-ainesato oli keskimäärin 3400 $\mathrm{kg} \mathrm{ka} / \mathrm{ha}$, toisen sadon noin $3910 \mathrm{~kg} \mathrm{ka} / \mathrm{ha}$ ja kolmannen noin $1940 \mathrm{~kg} \mathrm{ka} / \mathrm{ha}$; tasoerot näkyivät myös satomäärää viitteellisesti kuvaavissa LAI-maksimeissa, vaikka LAI-maksimit tai niittohetken LAIarvot eivät selittäneet satotasoja (Kuva 1). Satotasot ja LAI:t viittaavat siihen, että sinimailanen kehittyy nopeasti mutta ei täytä maksimaalista satopotentiaaliaan ensimmäisessä korjuussa. Toisen sadon kehitys on ensimmäistä hitaampaa, mutta sinimailasen jälkikasvukyky on hyvä verrattuna useisiin heiniin (Luke 2015). Kolmen sadon yhteenlaskettu satotaso $9250 \mathrm{~kg} \mathrm{ka} / \mathrm{ha}$ on heiniin verrattuna hyvä ottaen huomioon käytetty typpilannoitustaso: heinille kolmessa niitossa annetaan 150 - $220 \mathrm{~kg} \mathrm{~N} / \mathrm{ha}$, mutta tässä kokeessa sinimailanen sai kahdelle sadolle yhteensä vain $93 \mathrm{~kg} \mathrm{~N} / \mathrm{ha}$. Sinimailasen typpitaseet olivatkin kolmessa niitossa noin $-210 \mathrm{~kg} \mathrm{~N} / \mathrm{ha}$ (tuloksia ei esitetty).

Kasvustojen korkeudessa havaittiin eroja lajikkeiden välillä, ja Artemis ja Alexis olivat korkeimpia erityisesti toisessa ja kolmannessa sadossa (Taulukko 1). Kasvuston korkeus selitti satotasoeroja vain kolmannessa niitossa $\left(r^{2}=0,64\right)$. Lakoisuutta havaittiin vain toisessa niitossa, jolloin 
Alexis ja Artemis olivat laonkestävimmät lajikkeet (Taulukko 1). Myös kasvustojen kehitysasteet erosivat toisistaan vain toisessa niitossa, jolloin Alexis ja Artemis jälleen erottuivat aloittamalla kukinnan muita aikaisemmin (Taulukko 1). Viileän alkukesän takia nurmipalkokasvien kukinta viivästyi huomattavasti ja ensimmäinen niitto jouduttiin tekemään selkeästi ennen tyypillistä korjuuaikasuositusta.

Taulukko 1. Sinimailas lajikkeiden sato (kg ka/ha), kasvuston korkeus (cm), lakoisuus (\%) ja BBCH-asteikon mukainen kehitysaste ensimmäisessä, toisessa ja kolmannessa niitossa $(n=4)$ Luke Ylistarossa kas vukaudella 2015. Tilastollisesti toisistaan eroavat $(p<0,05)$ lajikkeet on merkitty eri aakkosin $(\mathrm{a}, \mathrm{b}, \mathrm{c})$ ja tendenssi $(p<0,10)$ tilastolliseen eroon plus - tai miinusmerkillä $(+,-)$.

Niitto 1

Niitto 2

Niitto 3

\begin{tabular}{|c|c|c|c|c|c|c|c|c|c|c|c|c|}
\hline \multirow[b]{2}{*}{ Lajike } & & & \\
\hline & Sato & Korkeus & Lako & BBCH & Sato & Korkeus & Lako & ВBCH & Sato & Korkeus & Lako & ВВСН \\
\hline Alexis & $3297 \mathrm{a}$ & $57,6 \mathrm{a}$ & $0 \mathrm{a}$ & 39 a & $3890 \mathrm{a}$ & 88,8 a & $15 \mathrm{a}$ & $61,0 \quad \mathrm{a}$ & $2098 \mathrm{a}$ & $67,5 \mathrm{a}$ & $0 \mathrm{a}$ & 52,8 a \\
\hline Artemis & $3541 \mathrm{a}$ & - . & $0 \mathrm{a}$ & - . & 3831 a & $92,5 \mathrm{a}$ & $15 \mathrm{a}$ & $61,8 \mathrm{ab}$ & $2293 \mathrm{a}$ & 67,0 a & $0 \mathrm{a}$ & 52,0 a \\
\hline Lavo & $3117 \mathrm{a}$ & 54,3 a & $0 \mathrm{a}$ & 38 a & 3707 a & $82,5 \mathrm{ab}$ & $60 \mathrm{~b}$ & 59,8 ac & $1535 \mathrm{~b}$ & $53,3 \mathrm{~b}$ & $0 \mathrm{a}$ & 51,3 a \\
\hline Live & 3573 a & $57,5 \mathrm{a}$ & $0 \mathrm{a}$ & $39,0 \mathrm{a}+$ & $4447 \mathrm{a}+$ & $80,8 \mathrm{~b}$ & $55 \mathrm{~b}$ & $59,8 \mathrm{ac}$ & $2067 \mathrm{a}$ & $61,0 \mathrm{ab}$ & $0 \mathrm{a}$ & 51,5 a \\
\hline Nexus & $3472 \mathrm{a}$ & $52,9 \mathrm{a}-$ & $0 \mathrm{a}$ & $38,0 \mathrm{a}$ & $3685 \mathrm{a}$ & $81,8 \mathrm{~b}$ & $43 \mathrm{~b}$ & $59,5 \mathrm{c}$ & $1717 \mathrm{~b}$ & $56,5 \mathrm{~b}$ & $0 \mathrm{a}$ & 52,8 a \\
\hline keskiarvo & 3400 & 55,6 & 0 & 38,5 & 3912 & 5,3 & 38 & 60,4 & 1942 & 61,1 & $\mathbf{0}$ & 52,1 \\
\hline SEM & 199,7 & 1,43 & 0 & 0,4 & 287,4 & 2,21 & 6,8 & 0,4 & 97,7 & 2,35 & 0 & 1,4 \\
\hline$p$-arvo & & $o$ & & & & $*$ & $* *$ & $* *$ & $* *$ & $* *$ & & \\
\hline
\end{tabular}

\section{Sadon sulavuus ja kuitupitoisuus sekä D-arvoa selittävät tekijät}

Lajikkeiden välisiä eroja rehuarvoissa ei voitu selvittää tilastollisesti ensimmäisessä niitossa, sillä näytteet oli yhdistetty lajikkeittain $(n=1)$. Tulokset kertovat silti viitteellisesti lajikkeiden mahdollisista eroista, sillä kukin lajikkeen rehunäytteeseen oli koottu osanäytteet $(n=4)$ kaikista kerranteista. Toisesta ja kolmannesta niitosta kultakin koejäseneltä analysoitiin kolmen kerranteen näytteet $(n=3)$.

Lajikkeiden D-arvot ja kuitu- tai tuhkapitoisuudet eivät eronneet tilastollisesti toisistaan lukuun ottamatta Alexiksen ja Artemiksen $(p=0,09)$ muita korkeampaa sulamattoman kuidun (iNDF) pitoisuutta toisessa niitossa (Taulukko 2). Kaikissa niitossa korkein D-arvo oli Lavolla, toisessa niitossa myös Liven ja Nexuksen D-arvot olivat lähellä Lavon sulavuutta. D-arvot olivat kauttaaltaan tyypillistä säilörehun D-arvon tavoitetasoa (680 - $700 \mathrm{~g} / \mathrm{kg} \mathrm{ka}$ ) matalampia. Erityisesti toisen sadon Darvot olivat hyvin matalia. Taannoisessa Feedipedian sinimailas-metatutkimuksessa oli havaittu yhtä alhaisia sulavuuksia noin 9 viikon niittovälillä (Baumont ym., 2014). Sulavuuden osalta tulokset ovat samaa tasoa kuin ulkomaisissa sinimailasen kehitysrytmikokeissa on havaittu (Baumont ym. 2014). Nurmiheiniin verrattuna sinimailasen iNDF-pitoisuudet olivat suhteellisen korkeita, erityisesti toisessa niitossa (Luke 2015).

Usein korkea satotaso, kasvuston korkeus tai pitkälle edistynyt kehitysaste madaltaa sulavuutta. Koska tässä kokeessa lajikkeiden välillä ei havaittu selkeitä eroja satotasoissa tai D-arvoissa kolmatta satoa lukuun ottamatta, ei satomäärä selittänyt matalia D-arvoja kuin lievästi kolmannessa niitossa $\left(r^{2}=0,45\right)$. LAI-arvo ei selittänyt D-arvon tai iNDF-pitoisuuden kohoamista. Mitatuista tai havainnoiduista ominaisuuksista D-arvon laskua selittivät kasvava BBCH-kehitysaste $\left(r^{2}=0,85\right)$ ja lisääntyvä kasvuston korkeus $\left(r^{2}=0,79\right)$ yli niittokertojen tarkasteltuna (Kuva 2A). Koska D-arvon ja iNDF-pitoisuuden välillä havaittiin lähes täydellinen negatiivinen korrelaatio $\left(r^{2}=0,996\right)$, selittivät samat tekijät yhtä vahvasti myös kasvuston iNDF-pitoisuuden nousua: kasvava BBCH-kehitysaste $\left(r^{2}=0,84\right)$ ja lisääntyvä kasvuston korkeus $\left(r^{2}=0,78\right.$; Kuva $\left.2 \mathrm{~B}\right)$. Lämpösumman vaikutusta $\mathrm{D}$-arvon tai iNDF-pitoisuuden kehitykseen ei voitu selvittää, sillä tässä kokeen aikana havaintoja kertyi vain kolmesta eri lämpösummasta ja nekin kaikki eri niittokerroilta. 
Taulukko 2. Sinimailas lajikkeiden D-arvo, NDF-kuidun, sulamattoman iNDF-kuidun ja tuhkan pitoisuus (g/kg ka) ensimmäisessä $(n=1)$, toisess a ja kolmannessa niitossa $(n=3)$ Luke Ylistarossa kas vukaudella 2015. Tilastollis esti toisistaan eroavat $(p<0,05)$ lajikkeet on merkitty eri aakkos in $(\mathrm{a}, \mathrm{b}, \mathrm{c})$ ja tendenssi $(p<0,10)$ tilastolliseen eroon plustai miinus merkillä $(+,-)$.

\begin{tabular}{|c|c|c|c|c|c|c|c|c|c|c|c|c|}
\hline \multirow[b]{2}{*}{ Lajike } & \multicolumn{4}{|c|}{ Niitto 1} & \multicolumn{4}{|c|}{ Niitto 2} & \multicolumn{4}{|c|}{ Niitto 3} \\
\hline & D-arvo & NDF & iNDF & Tuhka & D-arvo & NDF & iNDF & Tuhka & D-arvo & NDF & iNDF & Tuhka \\
\hline Alexis & 662 & 379 . & 124 . & 70 & 585 a- & $465 \mathrm{a}$ & $185 \mathrm{a}+$ & $75 \mathrm{a}$ & $634 \mathrm{a}$ & $397 \mathrm{a}$ & $143 \mathrm{a}$ & $88 \mathrm{a}$ \\
\hline Artemis & 656 & 386 & 124 & 79 & 587 a- & $461 \mathrm{a}$ & $183 \mathrm{a}+$ & $81 \mathrm{a}$ & $626 a$ & $406 \mathrm{a}$ & $150 \mathrm{a}$ & $90 \mathrm{a}$ \\
\hline Lavo & 679 & 372 & 108 & 79 & 598 a & $462 \mathrm{a}$ & $172 \mathrm{a}$ & $81 \mathrm{a}$ & $650 a+$ & 381 a- & 130 a- & 89 a \\
\hline Live & 664 & 376 & 119 & 77 & 596 a & $451 \mathrm{a}$ & $177 \mathrm{a}$ & $78 \mathrm{a}$ & $625 \mathrm{a}$ & $400 \mathrm{a}$ & $153 \mathrm{a}$ & $87 \mathrm{a}$ \\
\hline Nexus & 669 & 372. & 116 & 74 & 596 a & $448 \mathrm{a}$ & $175 \mathrm{a}$ & $76 \mathrm{a}$ & $630 \mathrm{a}$ & $394 \mathrm{a}$ & $150 \mathrm{a}$ & $88 \mathrm{a}$ \\
\hline keskiarvo & 666 & 377 & 118 & 76 & 592 & 457 & 179 & 78 & 633 & 396 & 145 & 88 \\
\hline SEM & - & - & - & - & 4,0 & 7,0 & 3,1 & 2,3 & 7,9 & 7,8 & 7,1 & 1,3 \\
\hline p-arvo & - & - & - & - & & & $o$ & & & & & \\
\hline
\end{tabular}
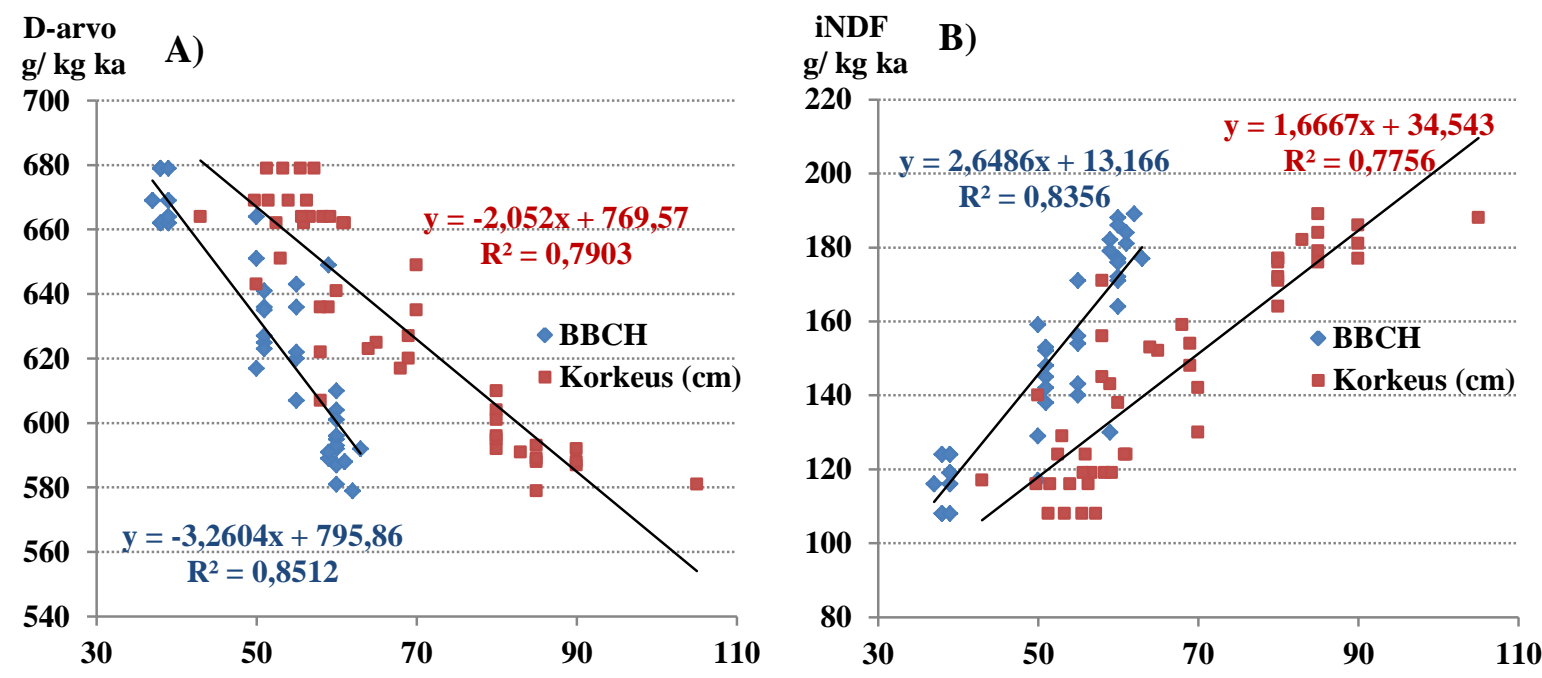

Kuvat 2A ja 2B. Puhtaiden sinimailaskasvustojen D-arvo (A) sekä kasvuston iNDF-kuitupitoisuus (B) suhteessa kasvuston BBCH-kehitysasteeseen ja korkeuteen $(\mathrm{cm})$ kasvukaudella 2015. Regressiot on tehty yli lajikkeiden $(n=5)$ ja niittokertojen $(n=3)$. Ensimmäisen sadon niitossa lajikkeista on ainoastaan koejäsenittäin yhdistetyt rehuarvotiedot käytettävissä $(n=1)$, toisen ja kolmannen sadon niitosta tulokset ovat koeruuduittain kolmesta kerranteesta $(n=3)$.

\section{Sadon valkuais- ja sokeripitoisuus}

Ensimmäisessä niitossa korkein raakavalkuaispitoisuus oli Lavo-lajikkeella, ja Alexiksen valkuaispitoisuus näytti olevan matalin (Taulukko 3), mutta tilastollisia eroja ei voitu selvittää (kunkin lajikkeen analyysitulosten $n=1$ ). Toisessa niitossa valkuaispitoisuudet olivat hyvin samankaltaisia ensimmäiseen niittoon verrattuna ja Alexiksen raakavalkuaispitoisuus oli $(p=0,09)$ hieman muita lajikkeita matalampi. Kolmannessa niitossa valkuaispitoisuudet olivat erityisen korkeita kahteen edelliseen niittoon verrattuna. Tilastollisia eroja kolmannen niiton valkuaispitoisuuksissa ei havaittu, mutta Lavon valkuaispitoisuus ja ohutsuolesta imeytyvän valkuaisen pitoisuus (OIV) olivat hieman muita korkeammat. Pötsin valkuaistaseissa (PVT) eroja ei havaittu. Raakavalkuaispitoisuudet olivat selvästi korkeammat kuin samaan aikaan niitettävillä heinänurmilla ja samalla tasolla kuin ulkomaisissa tutkimuksissa samalla kehitysasteella niitettäessä (Luke, 2015; Baumont ym., 2014).

Pelkistävien sokerien osalta lajikkeiden välillä ei havaittu eroja, mutta sinimailasen sokeripitoisuudet olivat matalia heiniin verrattuna, millä saattaa olla vaikutusta rehun säilöttävyyteen (Luke, 2015; Vuorinen \& Takala, 1993). Erityisesti kolmannen sadon valkuaispitoisuudet olivat korkeita ja samaan aikaan sokeripitoisuudet erittäin matalia, mihin saattaa lisätä säilönnän epäonnistumisen riskiä sekä altistaa kasvuston talvituhoille. 
Taulukko 3. Sinimailas lajikkeiden raakavalkuais pitoisuus (RV, g/kg ka), ohutsuolesta imeytyvän valkuaisen pitoisuus (OIV, g/kg ka), pötsin valkuaistase (PVT) ja pelkistävien sokerien pitoisuus ( $\mathrm{g} / \mathrm{kg} \mathrm{ka})$ ensimmäisessä $(n=1)$, toisessa ja kolmannessa niitossa $(n=3)$ Luke Ylistarossa kas vukaudella 2015. Tendenssi $(p<0,10)$ tilastolliseen eroon on merkitty parivertailua kuvaavan aakkosen (a) oheen plus- tai miinus merkillä (+, -).

\begin{tabular}{|c|c|c|c|c|c|c|c|c|c|c|c|c|}
\hline \multirow[b]{2}{*}{ Lajike } & \multicolumn{4}{|c|}{ Niitto 1} & \multicolumn{4}{|c|}{ Niitto 2} & \multicolumn{4}{|c|}{ Niitto 3} \\
\hline & RV & OIV & PVT & Sokeri & RV & OIV & PVT & Sokeri & RV & OIV & PVT & Sokeri \\
\hline Alexis & 181. & 84 & 57. & 114. & 178 a- & 76 a- & $67 \mathrm{a}-$ & $72 \mathrm{a}$ & $255 \mathrm{a}$ & $89 \mathrm{a}$ & $126 \mathrm{a}$ & $49 \mathrm{a}$ \\
\hline Artemis & 190 & 84 & 66 & 104 & $196 \mathrm{a}$ & $78 \mathrm{a}$ & $82 \mathrm{a}$ & $63 \mathrm{a}$ & $250 \mathrm{a}$ & $88 \mathrm{a}$ & $123 \mathrm{a}$ & $49 \mathrm{a}$ \\
\hline Lavo & 214 & 89 & 83 & 98 & $204 \mathrm{a}$ & $80 \mathrm{a}+$ & $87 \mathrm{a}$ & $62 \mathrm{a}$ & $272 a+$ & $92 \mathrm{a}+$ & $139 \mathrm{a}+$ & $48 \mathrm{a}$ \\
\hline Live & 205 & 87 & 77 & 101. & $193 \mathrm{a}$ & 79 a & $78 \mathrm{a}$ & $77 \mathrm{a}$ & $251 \mathrm{a}$ & $88 \mathrm{a}$ & $124 \mathrm{a}$ & $55 \mathrm{a}$ \\
\hline Nexus & 196 & 86 & 69 & 107 & $195 \mathrm{a}$ & $79 \mathrm{a}$ & $80 \mathrm{a}$ & $75 \mathrm{a}$ & $259 \mathrm{a}$ & $89 \mathrm{a}$ & $131 \mathrm{a}$ & $54 \mathrm{a}$ \\
\hline keskiarvo & 197 & 86 & 70 & 105 & 193 & 78 & 79 & 70 & 257 & 89 & 129 & 51 \\
\hline SEM & - & - & - & - & 5,9 & 0,8 & 5,1 & 6,3 & 7,0 & 1,6 & 5,0 & 3,1 \\
\hline p-arvo & - & - & - & - & $o$ & $o$ & $o$ & & & & & \\
\hline
\end{tabular}

\section{Korjuuaikaoptimin määrittely}

Puhtaan sinimailaskasvuston ensimmäinen niitto olisi tämän kokeen tulosten perusteella järkevää tehdä viimeistään nuppuvaiheen lopulla. Rehuarvotulokset erityisesti toisesta niitosta viittaavat siihen, että puhdas sinimailaskasvusto menettää sulavuutensa nopeasti jälkikasvussa ja korjuu olisi tehtävä huomattavasti aikaisemmalla kehitysasteella. Niiton aikaistamisen negatiivisena puolena saattaa olla matalampi satomäärä, mutta satomäärämaksimi saattaa täyttyä jo aikaisemmin toisen sadon kehityksen aikana: tätä tukevat havainnot siitä, että LAI-maksimit saavutettiin toisessa sadossa jo pari viikkoa ennen niittoa suosituskehitysasteella. Baumontin ym. (2014) mukaan toisen niiton sulavuus olisi tavoitetasolla, kun jälkikasvun niitto tehdään 5 viikkoa ensimmäisen sadon korjuusta. Suomen oloissa optimi voisi olla LAI-mittauksien perusteella 5-6 viikkoa ensimmäisen niiton jälkeen.

\section{Johtopäätökset}

Puhtaiden sinimailaskasvustojen korjuusuosituksia voi olla syytä muuttaa, mikäli halutaan tavoitella korkeaa satotasoa ja silti hyviä rehuarvoja. Tämän yksivuotisen kokeen tulosten perusteella niitto tulisi tehdä nykyistä korjuusuositusta aiemmin: ensimmäisessä niitossa on pyrittävä niittämään kasvusto viimeistään myöhäisessä nuppuvaiheessa ja toisessa korjuussa huomattavasti aikaisemmin nuppujen alkaessa kehittyä. Tällöin sinimailasen kasvurytmiksi muodostuu helposti kolmen korjuun rytmi. Sinimailasen optimaalisen korjuurytmin selvittämiseksi Suomen oloissa tarvitaan lisää tutkimuksia.

Sinimailasen D-arvon kehityksestä ei ole toistaiseksi kehitetty ennustemallia tai -palvelua viljelijöiden tarpeisiin. Tässä kokeessa suhteellisen hyvin toimiviksi mittareiksi havaittiin kasvuston kehitysaste ja korkeus. Lämpösumman vaikutusta tässä kokeessa ei voitu testata vähäisten niittoajankohtien vuoksi. Edellä mainittujen muuttujien vaikutus sinimailasen D-arvon kehitykseen tulisi selvittää tarkemmin monivuotisissa kenttäkokeissa, joissa olisi myös eri niittoajankohtia.

\section{Kirjallisuus}

Baumont, R., Heuze, V., Tran, G. \& Boval, M. 2014. Alfalfa in ruminant diets. Legume Perspectives 4:36-37. Kaatz, P. 2015. Harvest schedule for first cutting alfalfa - Growing degree day differences abound across Michigan in 2015 from north to south. Michigan State University Extension-uutiskirje. Saatavissa: http://msue.anr.msu.edu/news/harvest_schedule_for_first_cutting_alfalfa

Lancashire, P.D., Bleiholder, H., Langeluddecke, P., Stauss, R., van den Boom, T., Weber, E. \& WitzenBerger, A. 1991. A uniform decimal code for growth stages of crops and weeds. Ann. Appl. Biol. 119: 561-601. Luke. 2015. Virallisten lajikekokeiden tulokset 2007-2014. Luonnonvara- ja biotalouden tutkimus 3/2015.

Myers, D. K. \& van Keuren, R. W. Fall alfalfa management. Factsheet AGF-009-90. Ohio State University Extension. Saatavissa: http://ohioline.osu.edu/agf-fact/0009.html

Niskanen, M. 2013. Nurmet. Korjuu. Virallisten lajikekokeiden suoritusohjeet vuodelle 2014. MTT.

ProAgria Oulu. Sini- ja rehumailanen viljelykasvina ja käyttö ruokinnassa. YmpäristöAgro tiedottaa -tietokortti. Saatavissa: http://www.proagriaoulu.fi/files/ymparistoagro/mailaset_viljelyssa_ja_ruokinnassa_+_tilaesimerkki.pdf Vuorinen, M. \& Takala, M. 1993. Sinimailasen viljelyyn vaikuttavia tekijöitä. Maatalouden tutkimuskeskus, Tiedote 16/93: $17 \mathrm{~s}$. 